\title{
A MODEL OF AUTHENTIC TEACHING MATERIALS FOR GENERAL ENGLISH SUBJECT
}

\author{
RyaniYulian, Yuniarti, Yuniarti \\ Universitas Muhammadiyah Pontianak \\ ryani.yulian@unmuhpnk.ac.id,yuniarti1406@unmuhpnk.ac.id,yuniarti@unmuhpnk.ac.id
}

Submitted: 2020-07-28

Accepted: 2020-11-05

\begin{abstract}
Designing teaching materials for General English at higher education has become a foundation of language teaching practices. The students at tertiary level should delineate the needs of the English language skill in the $21^{\text {st }}$ century. This study aimed to conduct need analysis to create a model of teaching materials that can accommodate university students to improve English proficiency skill. This study focused on the realm of designing teaching materials based on authentic materials in the area of reading skill supplemented with listening skill. The initial need analysis investigated students' needs of reading text, the needs of multimodal texts, the problems in reading and listening skill. The study also invigoratedthe level of critical thinking for critical reading, and the perspectives of lecturer in General English class. A sample of 230 students at Management Program was selected to participate as the sample represented the nature of the homogenous language skill. The results of the study revealed that students prefer to get exposure on authentic materials with multimodal images. They need to read materials that can catalyze critical thinking skill in critical reading. Also, listening materials can serveas an additional material to enrich the reading materials on the basis of sources of authentic materials.
\end{abstract}

Keywords: a model; teaching material; General English; authentic

\section{INTRODUCTION}

The alternation of designing materials for English language teaching has grown considerably based on the new paradigm coined by the experts in ELT under the framework of Teaching English as a Dynamic Language and Global English. Developing materials for English language teaching is necessary for English teachers. In the setting of the Universitas Muhammadiyah Pontianak, particularly at the Management Study Program Faculty of Economics and Business, the current teaching materials are still adopted and selected from various resources. As a matter of fact, the vast majority of the students have homogenous English proficiency skills that needs a representative coursebook for effective language learning. The expansion of the digital world and the internet requires the mastery of English language skill. The expertise of English proficiency skill has its potential market to obtain communicative skills at a work setting, to travel to different boundaries of the world, and to be active in diverse social interactions (Cozma, 2015). English is a means of communication in the today's era as the speakers of English outnumber the native speakers of English (Ke \& Cahyani, 2014).

result,theremustbeacoursebookforGeneralEnglishdesignedbasedontheneedsanalysisof 
the students to fulfil the demand to practise and use English language competence in the world and social setting.

The materials development of a coursebook should adhere to the systematic procedures, namely analysis, design, development, implementation, and evaluation. As the preliminary stage of this study, the researcher administered a needs analysis of the coursebook for General English and proceeded to the development of materials design and evaluation of the prototype of materials. The model of materials development adjusted to the model of materials development that considers the learning design as a systematical model and leads to the general stages commonly known as instructional system development: analysis, design, development, implementation and evaluations (Dick et al., 2001). The use of a relevant coursebook for university students is indispensable in the dynamic development of teaching and learning English. A coursebook designed by a needs analysis and various frameworks can assist the EFL teachers in the structured teaching management, and provide favourable assistance of language learners both inside and outside the classroom settings (Khodabakhshi, 2014). Needs analysis answers the needs to materials design since it is the preliminary stage to design the teaching materials, learning tasks, and systematic plan of evaluation in the language teaching and learning (Mehrdad,2012).

A contemporary teaching material also demands creative sources so that the coursebook of General English in this study was designed based on a multimodal approach and authentic materials. A multimodal approach is appropriate to lead the materials development process on higher education in the second language learning and multimodal approaches created favourable reactions and feedbacks from students toward multimodal integration learning activities (Kress, 2010; Jewitt, 2005). Reading text as learning materials developed based on multimodal pedagogical approaches can create a positive learning atmosphere, cater to learning autonomy, and expose to a variety of learning styles (Ganapathy, 2016).

Research on the needs analysis of designing material for General English is relatively new. Numerous researches focused on the needs analysis in English for Specific Purposes (ESP) in particular language skills but rarely considered the current demand of designing materials from the content of language skill for General English. A study by Moiinvaziri (2014) explored the needs analysis of General English subject from the students' preferred learning styles, attitudes, and self-motivation. The results showed the perceived problematic skills were listening and reading skill. Mehrdad, (2012) in his study conducted a need analysis in General English and investigated the dimensions based on the students' wants and lacks from the general perspectives, but none of language skills were considered. This present study attempted to fill the gap from the previous researches in terms of substantial elements of designing materialsfor 
specific language skills in General English course for novice learners of English at higher education with scope of reading skill. The significance of the study was to facilitate the process of teaching and learning English with validated teaching materials in reading and listening skill. The academic contribution can also provide a scientific analysis to the review of materials developments based on the needs of the students, the demands of students' future career, and the demands of validated problem-solving activity in teaching and learning English as a foreign language.

\section{METHOD}

The methodology underpinning this study was a model of material development by Dick, Carey and Carey which consists of five procedures of research and development, namely analysis, development, design, implementation, and evaluation(Dick et al., 2001). The sample of the study was 230 students of Management Program at the Faculty of Economics and Business Universitas Muhammadiyah Pontianak in the academic year 2019/ 2020. The sample was randomly selected as each student has the same characteristics, and the probability to be selected (Creswell, 2013). The sample was selected based on the whole population of the students who passed the General English subject. The tools of data collecting consisted of questionnaires of the students' need in reading text and multimodal text adapted from Boshrabadi\&Biria (2014). The validity and reliability of the questionnaire of the students' need in the reading text used SPSS Statistics Version 26. Self-rating questionnaires from Gravatt, Richards dan Lewis from the University of Auckland were also employed to examine the students' difficulties in reading and listening skill (Richard, Jack,2005).

This study adopted critical thinking for a critical reading rubric to analyze the students' reading competence as part of learners' analysis by Paul and Elder (2006). Reading comprehension test was given to examine the level of students' critical thinking for critical reading. For data triangulation, open-ended interview with team teaching lecturer in General English subject was conducted stick to the International Association for the Evaluation of Educational Achievement ((PIRLS 2006 Contextual Questionnaires, n.d.). The analysis of data interview used the thematic analysis both inductive and deductive coding approach by $\mathrm{Xu} \&$ Zammit (2020) starting from initializing codes, developing codes, and searching for themes. The initial step in data analysis was administering questionnaires to the students. The reading comprehension test was conducted consecutively and corroborated with the results of interview to design an outline for the teachingmaterials.

\section{FINDING AND DISCUSSION}

This part synthesizes the process of needs analysis. The first needs analysis focused on students' need in the reading text in general. The validity test was conducted by using Pearson Product Moment Correlations-SPSS Statistics Version 26. The test result showed that question 1 
to 16 were classified valid. Based on the significant value obtained by the Sig. ( 2 tailed) of $0.000<0.05$, all questions in this questionnaire were valid.

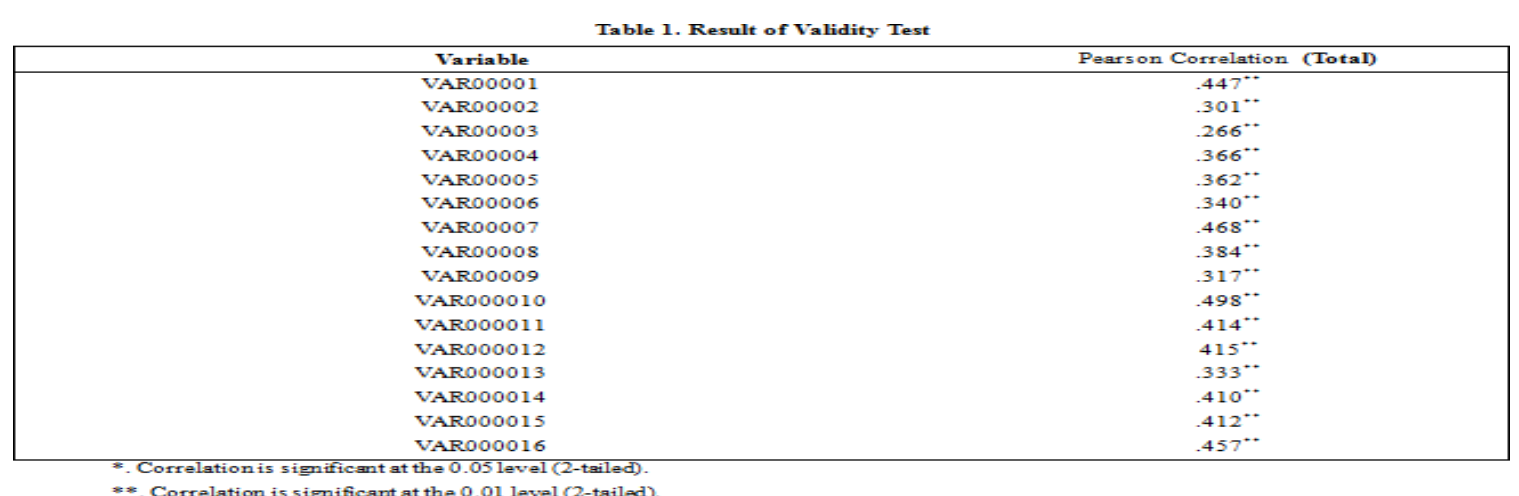

For examining the consistency of the measurement results, the reliability test was also conducted by using SPSS Statistics Version 26. The reliability test showed that the value of Cronbach's Alpha $>0.600$ categorized reliable.

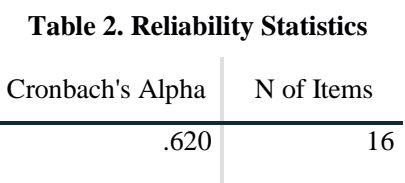

\section{Needs analysis questionnaire for students in reading text in general}

The questionnaire of students' need in reading text used Likert-scale ranging from Strongly Agree (5), Agree (4), Neutral (3), Disagree (2), and Strongly Disagree (1). There were sixteen elements to examine students' need in the reading text in general. The initial questions demonstrated that students are interested in authentic materials such as magazines and articles. The exposure of authentic materials can be useful because the availability of authentic texts can providereal examples of using the target language according to native speakers. The following elements in the questionnaire concerned with vocabulary enrichment activity through the integration of glossary study in the reading text. Vocabulary exposure activity is essential in language acquisition as it can enable students to read authentic texts (Ibrahim et al., 2016). Furthermore, the needs analysis came with a probe that vocabulary mastery can affect reading comprehension skills. Students have difficulty with unfamiliar and challenging words so that glossary study should be available in the pre-reading activity. The students' level of vocabulary mastery is closely related to the mastery of reading comprehension (Perfetti, 2007). The mean score and standard deviation of this analysis can be seen asfollow: 


\begin{tabular}{|c|c|c|c|}
\hline No. & Items of Questionnaire & Mean Score & SD \\
\hline 1. & I prefer to read authenticreading text suchas frommagazines and articles. & 3,54 & 0,67 \\
\hline 2. & I prefer to read reading text from a course or textbook. & 3,8 & 0,67 \\
\hline 3. & I prefer to read reading text with easy vocabulary and commonly used. & 4,33 & 0,49 \\
\hline 4. & $\begin{array}{l}\text { I prefer to read reading text with a varied level of difficulty in order to } \\
\text { increase my vocabulary. }\end{array}$ & 3,68 & 0,84 \\
\hline 5. & $\begin{array}{l}\text { I prefer to read reading text with difficult vocabulary because I am more } \\
\text { challenged to understand themeaning of words. }\end{array}$ & 3,23 & 0,91 \\
\hline 6. & $\begin{array}{l}\text { Glossary Study is very important to help me under standing the meaning of } \\
\text { words. }\end{array}$ & 4,14 & 0,69 \\
\hline 7. & Glossary Study only provides little vocabulary understanding forme. & 2,97 & 0,85 \\
\hline s. & Glossary Study has no effect on my understanding of vocabulary. & 2,6 & 0,84 \\
\hline 9. & $\begin{array}{l}\text { The exercises on the reading text should consist of simple activities such as } \\
\text { answering comprehension questions from the text. }\end{array}$ & 3,89 & 0,7 \\
\hline 10. & $\begin{array}{l}\text { The exercises on the reading text should consist of varied activities from } \\
\text { easy to difficult. }\end{array}$ & 3,97 & 0,74 \\
\hline 11. & $\begin{array}{l}\text { The exercises on the reading text should consist of activities which can } \\
\text { practice the students explore individual skills. }\end{array}$ & 4,06 & 0,7 \\
\hline 12. & I face difficulty when reading to 10 ng reading text. & 3,71 & 0,87 \\
\hline 13. & I face difficulty when reading text with difficult vocabulary. & 3,93 & 0,77 \\
\hline 14. & $\begin{array}{l}\text { I face difficulty if the topic of the reading text is not interesting and } \\
\text { irrelevant with my field of study. }\end{array}$ & 2,99 & 0,87 \\
\hline 15 . & The layout of the reading text should use formal letter without pictures. & 2,98 & 0,78 \\
\hline 16. & $\begin{array}{l}\text { The layout of the reading text should use varied fonts with moderate size } \\
\text { and insert with relevant, and contextual pictures related to the topic. }\end{array}$ & 3,79 & 0,76 \\
\hline
\end{tabular}

This need analysis questionnaire surveyed 176 participants from a total of 230 participants. Over 71 per cent of students are between 17 to 19 years old, and over 68,2 per cent are women. The data revealed that most students prefer to read reading text from magazines and articles as authentic materials $(3,54)$, and they also prefer to get a reading text from a coursebook $(3,8)$. In terms of vocabulary aspect, the students prefer to read a text with easy vocabulary commonly used in daily lives $(4,33)$; thus the glossary study is an integral part in the reading text to understand the text $(4,14)$. Students prefer to have varied activities from easy to difficult $(3,97)$, and they prefer to have individual skills based exercise $(4,06)$. Based on the aspects of students' difficulties in reading skill, the data indicated that too long reading text $(3,71)$, and difficult vocabulary in a reading text $(3,93)$ are the main problems. Finally, reading text should have an attractive layout so that the students prefer to read a text with a variety of fonts, size and pictures related to the topic $(3,79)$.

\section{Needs analysis questionnaire for students on multimodal texts}

In this questionnaire, the students expressed their perceptions toward the use of multimodal texts. The result discovered the strengths of multimodal text that encompass the basic skills of reading in the classroom. The reading texts accompanied by visual images and relevant graphics can assist better understanding for students because the element of visual images can link their prior knowledge to the reading text (Boshrabadi\&Biria, 2014). The elaboration of the need analysis questionnaire on the multimodal text can be seen as follow: 


\begin{tabular}{|c|c|c|c|}
\hline No. & Items of Questionnaire & Mean Score & SD \\
\hline 1. & I am interested in reading activities, using multimodal texts. & 4,18 & 0,68 \\
\hline 2. & Reading multimodal texts are more enjoyable and advantageous. & & \\
\hline 3. & $\begin{array}{l}\text { I would feel more confident completing reading activities when the text } \\
\text { is acoompanied by related images, videos, and/or audio recordings. }\end{array}$ & $4,1 \mathrm{~s}$ & 0,82 \\
\hline 4. & $\begin{array}{l}\text { I make faster pro gress in the } L \cdot 2 \text { reading comprehension when I read } \\
\text { texts accompanied by both images and audio tracks. }\end{array}$ & 4,02 & 0,82 \\
\hline 5. & $\begin{array}{l}\text { Processing different modes of a text while reading helps me better } \\
\text { recall the content of passage later. }\end{array}$ & 3,8 & 0,74 \\
\hline 6. & $\begin{array}{l}\text { Images/graphics of the text seve as an adequate resource in } \\
\text { understanding the text in foreign language reading class es. }\end{array}$ & 3,76 & 0,69 \\
\hline 7. & $\begin{array}{l}\text { I can easily summarize a given passage when it is accompanied by } \\
\text { related visual images or supplemental videos. }\end{array}$ & 3,93 & 0,71 \\
\hline s. & $\begin{array}{l}\text { At some stages of comprehension, thevisual images help me to } \\
\text { understand the text easier. }\end{array}$ & 3,92 & 0,73 \\
\hline 9. & $\begin{array}{l}\text { Visual images of the text help me recall the unknown vocabulary of the } \\
\text { text easier. }\end{array}$ & 3,87 & 0,73 \\
\hline 10. & $\begin{array}{l}\text { I tend to flash back to visual images of the passage whenever it is hard } \\
\text { to summarize thetext. }\end{array}$ & 3,77 & 0,74 \\
\hline
\end{tabular}

The results proved that students are interested in reading multimodal texts $(4,18)$, and they consider the multimodal text is enjoyable and advantageous $(4,18)$. Students also have more confidence when the text is accompanied by related images, videos, and recordings $(4,02)$.

Overall, the visual images of multimodal texts can help the students recall the problematic words and guess the meaning easier $(3,87)$, and visual images can lead the students to summarize the text easily $(3,77)$. The empirical data concluded that multimodal text can be a representative reading text to accommodate teaching and learning readingskill.

\section{Needs analysis questionnaire for non-english background students in reading skill}

This phase of analysis examined the students' reading skill based on their self-rating. Students still have problems to read various reading texts, both authentic and non-authentic materials. The main problems underlying reading comprehension covered basic skills in reading such as skimming, scanning, guessing words from context, understanding the structure of the text, and general understanding. These reading skills can accommodate higher reading competence for foreign language learners as the primary purposes of reading comprehension skill such as predicting, visualizing, summarizing, and making inference (Küçükoğlu, 2013). The analysis result of students' ability and problems in reading skill is as follows:

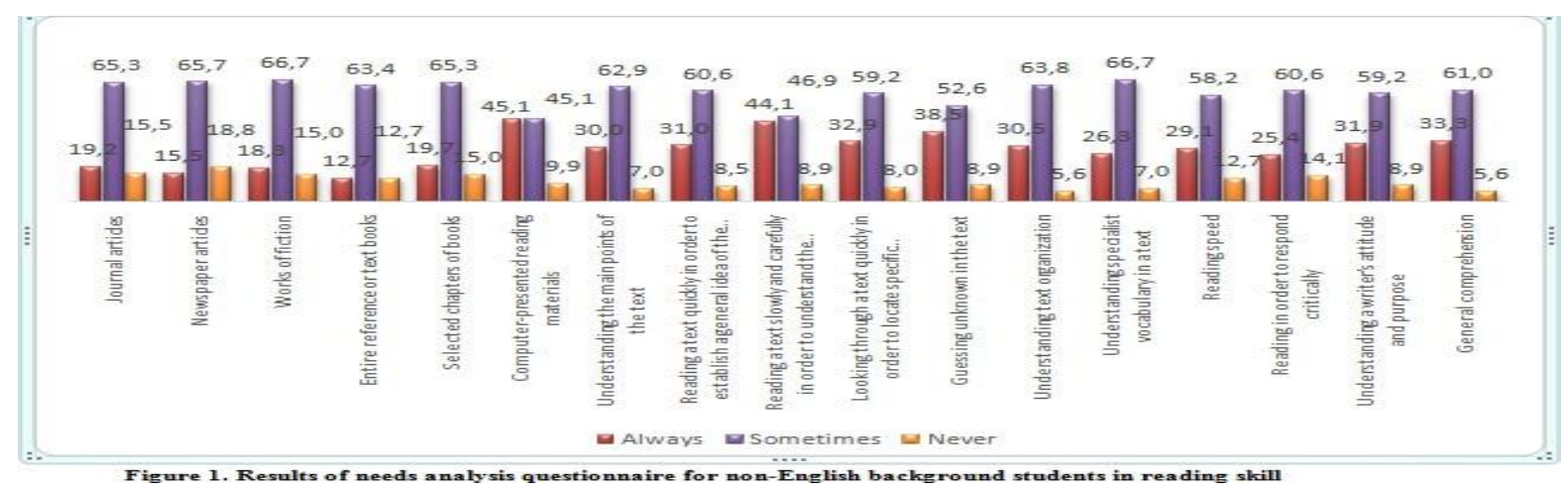


The data showed that students have difficulties in a variety of reading text as in journal articles $(19,2 \%)$, newspaper articles $(15,5 \%)$, works of fiction $(15,0 \%)$, complete reference of books $(12,7 \%)$, selected chapters of books $(19,7 \%)$, and computer-presented reading materials $(45,1 \%)$. Students have problems in sub-skills of reading such as to understand the main points of the text (30\%), and to establish a general idea of the content of the reading a text quickly (31\%). The other main problems are to read a text slowly and carefully in order to understand the details of the text $(44,1 \%)$, to look through a text quickly in order to locate specific information $(32,9 \%)$ and to guess unknown in the text $(38,5 \%)$. Besides, students have problems to understand text organization $(30,5 \%)$, to understand specialist vocabulary in a text $(26,3 \%)$, to have reading speed $(29,1 \%)$, and to read in order to respond critically $(25,4 \%)$. To understand a writer's attitude and purpose $(31,9 \%)$, and to obtain general comprehension $(33,3 \%)$ are also theproblems.

\section{Needs analysis questionnaire for non-english background students in listening skill}

For novice learners of English, the material developments also underpin the materials for listening skill since students must have various exposure to get the input of the language practice. To corroborate the needs analysis in reading skill, the researcher also examined the students' ability and problem in listening skill. Students must improve their listening skill as one of the subskills of comprehension skills in English because this skill cannot emerge instantly. Listening plays a vital role in all spheres of language learning and can supplement the activity of reading to the best way of improving reading skill(Idrissova et al., 2015). Reading and listening skills are the central core of materials development in this study. These skills are closely related because the receptive skills are useful to provide language input before students can use productive skills. The attributes of the needs analysis questionnaire for Non-English background students in listening skill can be seen in the followingfigure:

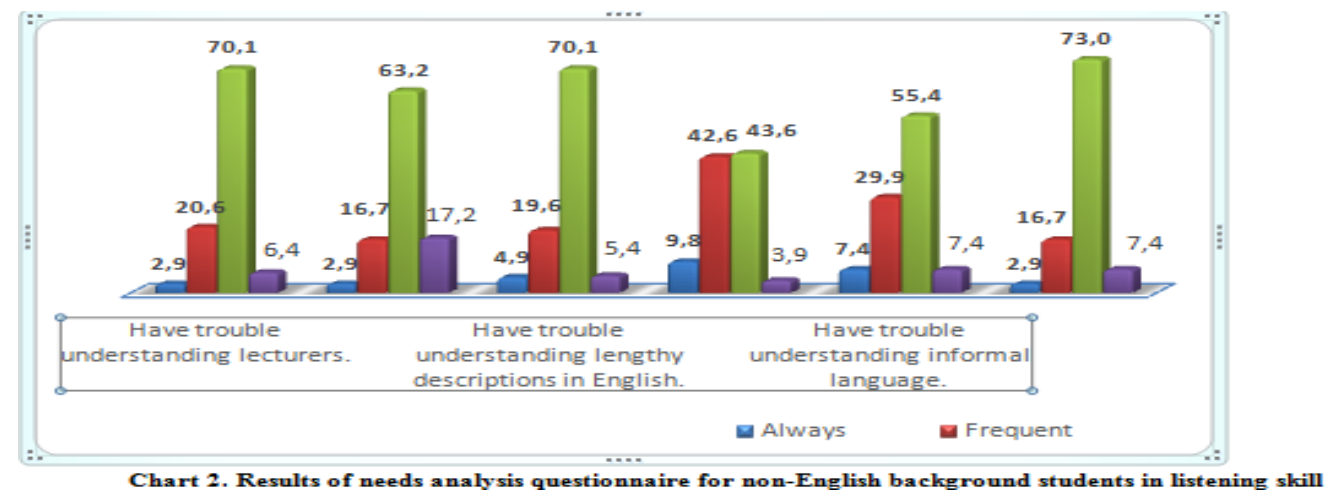

The analysis encountered some problems in listening skill as in students still have frequent trouble in understanding lecturers $(70,1 \%)$, students have to ask lecturer questions to clarify material taught $(16,7 \%)$, and students have trouble understanding lengthy descriptions in English (19,6\%). The results also underlined that students have trouble in understandingspoken 
instructions $(42,6 \%)$, students have trouble in understanding informal language $(29,9 \%)$, and students have trouble in understanding the subject matter of a talk (16,7\%). Regarding the problems in listening skill, authentic materials for listening skill is beneficial to accommodate teaching and learning activities where the students will become familiar with the expressions in real-life situations. They can provide motivation to enrich the use of real language for the students and assist them to be more interactive with the content of learning language apart from the grammatical features (Ahmed, 2017).

\section{Results of students' critical thinking in critical reading}

The rubric of critical thinking for critical reading consists of four standards and elements, namely accuracy, clarity, precision and depth adapted from Paul and Elder (2006). In the element of accuracy, the students' skills were classified highly inaccurate, with wrong or no purpose or concepts stated with the mean score 1,12. In the element of clarity, the student' skills were categorized in level 2, which means incorrect or minimal use of the facts, data, or examples from the reading with the mean score 1,99. Students' skills in the element of precision were categorized in low precision; an attempt to use the content-specific vocabulary, but uses incorrectly or minimally with the mean score 2,02 . The assessment revealed that students' skills of the element of depth were classified in level 1. Students have no understanding of the connections among purpose, concepts, and/or support in the reading with the mean score1,1.

\section{Thematic analysis of open-ended interview with general English lecturer}

The thematic analysis of the interview with General English lecturer created the emerging themes for the levels of students' reading competencies. In Bloom's taxonomy level of remembering, understanding, applying and analyzing, students' reading skills were categorized in the intermediate level. The students' reading skills were categorized in low level for the aspects of evaluating and creating. Regarding these levels of competence, students must get exposure to various reading materials. The materials should be appropriate with students' level of competences. The reading materials should accommodate activities such as warming-up questions or brainstorming activity, getting familiar with the vocabulary with glossary study, comprehension questions, detailed questions, matching questions, and reviewing activities. The activities of listening cover several listening sub-skills such as discerning main ideas, understanding sequence, noticing specific details, inferring, and comparing based on the needs analysis of students' self-rating in listening skill (Richard, Jack, 2005). The reading materials were supplemented with relevant pictures to the students' prior knowledge so that they can be more interested in the readingtext.

\section{Expert evaluation for model of teaching materials}

The evaluation covers several aspects from the alignment of general and specific instructional objectives of the materials, the appropriateness of the language use, topic, and 
vocabulary, the variety of learning activities, and the aspect of learners' factors (Dick et al., 2013; Smaldino, Lowther, \& Russell, 2008). The materials fulfilled the standard criteria based on the alignment to standards, outcome, and objectives. The elaboration of materials is acceptable, with clear learning objectives. The language, topic, and vocabulary are suitable for novice readers at the university level. The expert evaluated the aspects of self, peer, and lecturer assessment. The researcher needs to revise and integrate a comprehensive assessment in the materials because novice readers should obtain implicit instructions of assessment in teaching and learning activity.

\section{CONCLUSION}

The findings of the study revealed that novice learners of English at tertiary level demand appropriate teaching materials that suit their needs and abilities. The study showed that authentic materials and multimodal approach can be the basic framework for relevant material development in teaching and learning English as a foreign language. The dynamic of critical thinking for university students also play a crucial aspect to be integrated into materials development due to the qualities of critical reading will affect the success of languagelearning.

Needs analysis is the fundamental step in this study which set the goal, the purpose and the program. Needs analysis identified the prioritized needs by reviewing the materials based on the gaps between the theoretical concepts and empirical data. Importantly, the study conducted learners and contexts analysis, and instructional analysis simultaneously. All comprehensive analysis provided guidelines and frameworks for materials development. Then, the researcher developed a suitable instructional strategy and selected instructional materials based on the multimodal approach and authentic materials. The final stage was the expert evaluation of the prototype model of teachingmaterials.

This study has some limitations in terms of administering the instructional system development on analysis, development, and design. It merely focused on needs analysis and developed the prototype model of teaching materials. The future research will focus on the implementation and validation of the materials. Finally, this study can encourage non-native English teachers all over the world to design and create materials based on the needs analysis through systematic procedures in materials development. The materials development is no longer the domination of English teachers from English speaking countries since English has been a global and a dynamiclanguage. 


\section{ACKNOWLEDGEMENTS}

This study was funded by Kemenristek/BRIN for the research grant of PenelitianDosenPemula (PDP) Scheme 2019/2020.

\section{REFERENCES}

Ahmed, S. (2017). Authentic ELT Materials in the Language Classroom: An Overview Authentic ELT Materials in the Language Classroom : An Overview. April.

Boshrabadi, A. M., \& Biria, R. (2014). the Efficacy of Multimodal Vs. Print-Based Texts for Teaching Reading Comprehension Skills To Iranian High School Third Graders. International Journal of Language Learning and Applied Linguistics World (IJLLALW), 5(1), 365-380. www.ijllalw.org

Cozma, M. (2015). The Challenge of Teaching English to Adult Learners in Today's World. Procedia - Social and Behavioral Sciences, 197(February), 1209-1214. https://doi.org/10.1016/j.sbspro.2015.07.380

Creswell, J. W. (2013). Educational Research: Planning, Conducting and Evaluating Quantitative and Qualitative Research. In Pearson (Fourth Ed). Pearson.

Dick, W., Lou, C., \& James, O, C. (2001). The Systematic Design of Instruction. AddisonWesley Educational Publisher.

Dick, W., Carey, L., \& Carey, J. O. (2013). A model for the systematic design of instruction. Instructional Design: International Perspectives: Theory, Research, and Models, 1, 361370.

E, S. S., Lowther, D. L., \& Russel, J. D. (2008). Instructional technology and media for learning (Ninth Ed). Pearson.

Ganapathy, M. (2016). The Effects of Using Multimodal Approaches in Meaning-Making of 21st Century Literacy Texts Among ESL Students in a Private School in Malaysia. $\begin{array}{lllll}\text { Advances in Language and Literary } & \text { Studies, }\end{array}$ https://doi.org/10.7575/aiac.alls.v.7n.2p.143

Ibrahim, E. H. E., Sarudin, I., \& Muhamad, A. J. (2016). The Relationship between Vocabulary Size and Reading Comprehension of ESL Learners. English Language Teaching, 9(2), 116. https://doi.org/10.5539/elt.v9n2p116

Idrissova, M., Smagulova, B., \& Tussupbekova, M. (2015). Improving Listening and Speaking Skills in Mixed Level Groups (on the Material of New English File). Procedia - Social and Behavioral Sciences, 199, 276-284. https://doi.org/10.1016/j.sbspro.2015.07.517

Jewitt, C. (2006). Technology, Literacy, Learning. A Multimodal Approach. Abingdon/New York: Routledge. 
Ke, I. C., \& Cahyani, H. (2014). Learning to become users of English as a Lingua Franca (ELF): How ELF online communication affects Taiwanese learners' beliefs of English. System, 46(1), 28-38. https://doi.org/10.1016/j.system.2014.07.008

Khodabakhshi, M. (2014). Choose a Proper EFL Textbook: Evaluation of "Skyline" Series. Procedia - Social and Behavioral Sciences, 98(1988), 959-967. https://doi.org/10.1016/j.sbspro.2014.03.505

Kress, G. (2010). Multimodality: a social semiotic approach to contemporary communication. Abing- don/New York: Routledge.

Küçükoğlu, H. (2013). Improving Reading Skills Through Effective Reading Strategies. Procedia - Social and Behavioral Sciences, 70, 709-714. https://doi.org/10.1016/j.sbspro.2013.01.113

Mehrdad, A. G. (2012). A subjective needs assessment of EGP students. Procedia - Social and Behavioral Sciences, 31(2011), 546-554. https://doi.org/10.1016/j.sbspro.2011.12.101

Moiinvaziri, M. (2014). Students' voice: A needs analysis of university General English coursein Iran. GEMA Online Journal of Language Studies, 14(1), 57-75. https://doi.org/10.17576/GEMA-2014-1401-05

Paul and Elder. (2006). The Miniature Guide to Critical Thinking: Concepts and Tools.

Perfetti, C. (2007). Reading ability: Lexical quality to comprehension. Scientific Studies of Reading, 11(4), 357-383. https://doi.org/10.1080/10888430701530730

Phantharakphong, P., \&Pothitha, S. (2014). Development of English Reading Comprehension by Using Concept Maps. Procedia - Social and Behavioral Sciences, 116, 497-501. https://doi.org/10.1016/j.sbspro.2014.01.247

PIRLS 2006 Contextual Questionnaires. (n.d.). Retrieved July 19, 2020, from https://timssandpirls.bc.edu/pirls2006/context_quest.html

Richard, Jack, C. (2005). Curriculum Development in Language Teaching. In Curriculum Development in Language Teaching (Series Ed). Cambridge University Press.

Xu, W., \& Zammit, K. (2020). Applying Thematic Analysis to Education: A Hybrid Approach to Interpreting Data in Practitioner Research. International Journal of Qualitative Methods, 19, 1-9. https://doi.org/10.1177/1609406920918810 